\title{
The Influence of Injected Fluids on Microscopic Pore Structures in the Intersalt Dolomitic Shale Oil Reservoirs
}

\author{
Tong Zhou, ${ }^{1}$ Wei Yan ${ }^{(D,},{ }^{2}$ Jianzheng Su, ${ }^{1}$ Xianglu Tang, ${ }^{2}$ Hao Tian, ${ }^{2}$ Wenbo Li, ${ }^{2}$ \\ Kongyang Wang, ${ }^{2}$ Ting Sun $\mathbb{D}^{2}{ }^{2}$ Ruyue Wang, ${ }^{1}$ Rusheng Zhang, ${ }^{1}$ and Jun Niu ${ }^{1}$ \\ ${ }^{1}$ Research Institute of Petroleum Exploration and Development of SINOPEC, Beijing 100083, China \\ ${ }^{2}$ China University of Petroleum-Beijing, Beijing 102249, China \\ Correspondence should be addressed to Wei Yan; yanwei289@126.com
}

Received 17 October 2018; Revised 12 February 2019; Accepted 29 August 2019; Published 28 November 2019

Guest Editor: Qianbing Zhang

Copyright (c) 2019 Tong Zhou et al. This is an open access article distributed under the Creative Commons Attribution License, which permits unrestricted use, distribution, and reproduction in any medium, provided the original work is properly cited.

\begin{abstract}
Given their low porosity and permeability, intersalt dolomitic shale oil reservoirs need to be developed via large-scale hydraulic fracturing to achieve economic effects. However, various lithologies and salt materials make these reservoirs vulnerable to salt mineral dissolution and recrystallization and salt plugging during development. This study investigated the variation rules of pore structures, porosity, and permeability of intersalt dolomitic shale oil reservoirs under the influence of hydraulic fracturing fluid. Correspondingly, a series of experiments (i.e., high-temperature and high-pressure soaking experiments, focused ion beam scanning helium ion microscope analyses, and porosity and pulse permeability tests) is performed on the Qian $3^{4}-10$ rhythmic intersalt dolomitic shales. Results show that distilled water dissolves the salt crystals inside the matrix pores to improve the reservoir permeability. However, the distilled water-rock interaction will cause the massive migration of salt minerals. By contrast, the supercritical $\mathrm{CO}_{2}$ can disperse salt particles, dredge the channels, and enlarge pores by expansion, but it has an overall weak capability of changing the pore structure and matrix permeability. To simulate the supercritical $\mathrm{CO}_{2} \mathrm{composite}$ fracturing, the mixed solution of supercritical $\mathrm{CO}_{2}$ and distilled water favors the salt dissolution effect in the water-based fracturing fluid and recovery enhancement by $\mathrm{CO}_{2}$. This solution can remarkably improve the reservoir porosity and permeability and avoid massive salt mineral migration and salt crystallization damage. This study is theoretically and practically important to the effective and enhanced development of intersalt dolomitic shale oil reservoirs.
\end{abstract}

\section{Introduction}

In recent years, shale oil has become a key area for unconventional oil and gas exploration and development after shale gas. China's continental basins have developed a number of lacustrine mud shale strata with wide distribution, high abundance of organic matter, large thickness, and huge potential for shale oil resource, and they are considered a strategic option for the sustainable development of old oilfields in the east [1]. Among them, intersalt dolomitic shale oil reservoirs in the Qianjiang Depression of the Jianghan Basin has become an important target for China's shale oil technology breakthrough due to its numerous oil-bearing strata, superior hydrocarbon source conditions, and good oil-bearing properties.
Intersalt dolomitic shale oil reservoirs in the Qianjiang Depression have become so effective that they require volumetric reconstruction through hydraulic fracturing. The production data after hydraulic fracturing show that the initial increase of production is good and that the daily production of a single well can reach 69.2 tons. However, after fracturing, the very high salinity of the fracturing fluid (up to $26 \times 10^{4}$ $\mathrm{mg} \mathrm{L}^{-1}$ ) is ubiquitous, and salt particle crystals can be seen in the flowback fluid. Moreover, the stable production time is short, usually one to four months. After this period, the production drops rapidly. Given the particularity of the intersalt dolomitic shale oil reservoir, the reservoir contains soluble salts, and a thick salt layer develops at the top of the reservoir. After the water-based fracturing fluid enters the reservoir, it dissolves the soluble salt minerals inside the rock, 
causing the migration and recrystallization of the salt minerals, which forms the "salt blockage" in the formation and wellbore. The seepage capacity near the wellbore gradually decreases, and the production decreases rapidly several months after the fracturing.

$\mathrm{CO}_{2}$ fracturing is one of the waterless fracturing techniques that has unique production-increasing effects, such as increasing fracture complexity, reducing damage, improving crude oil flow, and increasing formation energy [2-6]. In the early 1980s, $\mathrm{CO}_{2}$ fracturing has been used in oil/gas field practices and has achieved good production-increasing effects in many wells $[2,7,8]$. For intersalt dolomitic shale oil reservoirs, using $\mathrm{CO}_{2}$ fracturing can avoid the dissolution and recrystallization of salt minerals caused by water-based fracturing fluids.

In terms of physical properties, $\mathrm{CO}_{2}$ is easy to transform and can exist in gaseous, liquid, or supercritical fluid forms, which are primarily affected by pressure and temperature. When the temperature and pressure exceed $31.1^{\circ} \mathrm{C}$ and 7.38 $\mathrm{MPa}$, respectively, $\mathrm{CO}_{2}$ exists in a supercritical state. In this state, the intermolecular force of $\mathrm{CO}_{2}$ is small, the surface tension is zero, and the fluidity is so strong that molecules can enter any space larger than the supercritical $\mathrm{CO}_{2}$ molecule [9]. As $\mathrm{CO}_{2}$ is easily soluble in formation water and forms carbonic acid, it can dissolve minerals such as feldspar and carbonate in rock under reservoir pressure and temperature. Therefore, the physical properties of the reservoir and the mechanical properties of the rock are changed [8, 10-14]. However, the change processes of microscopic pore structures and the porosity/permeability of shale reservoirs during supercritical $\mathrm{CO}_{2}$ fracturing remain unknown. In addition, due to the differences in physical properties of shale reservoirs, the influence of supercritical $\mathrm{CO}_{2}$ on the physical properties of the reservoir is different.

To investigate the influence of water-based fracturing fluid and supercritical $\mathrm{CO}_{2}$ on the physical properties of an intersalt shale reservoir, a series of high-temperature and high-pressure shale immersion experiments was performed, followed by microscopic pore structure observation and porosity and pulse permeability tests. The pore structure, porosity, and permeability change of intersalt shale under different fluids and the damage law of salt crystallization on physical properties of shale are studied. The results are expected to provide theoretical support for the correct formulation of measures for stable production and increased production in intersalt shale oil reservoirs.

\section{Overview of the Region}

The Jianghan Basin is an inland salt lake basin. Under the closed, high-salinity, and strong-evaporation environment of the Qianjiang Formation of Paleogene in the Qianjiang Depression, thousands of meters of thick salt-bearing strata are deposited, and hundreds of salt cyclothem (a sedimentary cycle is a rhythm) have developed. Each cyclothem consists of upper and lower salt rocks and a set of carbon-rich laminated argillaceous dolomite, dolomitic mudstone, and calcium-glauber mudstone (or calcium glauber rock filled with cloud mudstone) strata in between. Each salt cyclothem generally has an approximate thickness of 5 to $12 \mathrm{~m}$ and can sometimes reach up to $20 \mathrm{~m}$. The formation is composed of hydrocarbon source and reservoir layers, which are blocked by upper and lower salt rock to form an intersalt dolomitic shale oil reservoir.

The intersalt dolomitic shale oil reservoir is a high-quality hydrocarbon source layer integrally, which is composed mainly of argillaceous dolomite facies followed by dolomitic mudstone [15]. Based on fluid compartment theory, the formation water in the intersalt shale reservoir is primary water with no external water interference [16, 17]. At the same time, salt minerals accumulate in the cracks and pore channels for over a long period of time under hightemperature and high-pressure conditions, resulting in no formation water, low reservoir permeability, and good sealing. On-site production data also indicate that wells without water injection measures have no produced water after production.

The object of the study is the intersalt dolomitic shale of Qian $3^{4}-10$ cyclothem in the Qianjiang Depression of the Jianghan Basin. Figure 1 presents the results of mineral composition analysis. The intersalt strata are primarily composed of mud, salt, and carbonate minerals. The upper part of the cyclothem is carbon-rich laminated argillaceous dolomite facies. The dolomite content is $12.8 \%$ to $78.2 \%$ with an average of $50.7 \%$. The average total content of carbonate minerals in argillaceous dolomite is $65.2 \%$. The middle part is carbonrich laminated dolomitic or calcareous mudstone facies. The argillaceous mineral content is relatively high, mainly feldspar minerals, which account for approximately $12.5 \%$ to $48.7 \%$ with an average of $44.5 \%$, followed by carbonate minerals, with an average of $40.2 \%$. The bottom of the cyclothem is mainly composed of glauberite mudstone facies, which consist of argillaceous, salt (mainly sodium chloride and glauberite), and carbonate minerals with indistinguishable contents. In general, the intersalt dolomite shale oil reservoir has a low clay mineral content (mainly chlorite and illite with an average content of $10.3 \%$ ) that shows characteristics of low clay minerals, low quartz, high sodium feldspar, and high carbon. In addition, the $3^{4}-10$ cyclothem of the intersalt dolomite shale oil reservoir has overall salt-bearing properties. The salt content of the upper and middle argillaceous dolomite and dolomite mudstones is relatively low, ranging from $2.5 \%$ to $9.1 \%$. The glauberite mudstone near the bottom of the cyclothem layer has a relatively high salt content of up to $46.6 \%$.

The physical properties of the different lithofacies of Qian $3^{4}-10$ cyclothem in the intersalt dolomite shale reservoir have obvious differences (Table 1). Based on the lithology statistics of several typical wells in the exploration area, the porosity distribution of mud dolomite is mostly between $6 \%$ and $15 \%$, and the permeability of around $45 \%$ of the sample is below $0.5 \times 10^{-3} \mu \mathrm{m}^{2}$. The porosity of dolomite mudstone is less than $25 \%$, with $50 \%$ of the samples concentrated in $9 \%$ to $12 \%$, and the permeability is basically below $0.5 \times$ $10^{-3} \mu \mathrm{m}^{2}$. The porosity of the glauberite mudstone varies widely (between $0 \%$ and $20 \%$ ), and the permeability is concentrated below $0.5 \times 10^{-3} \mu \mathrm{m}^{2}$, as shown in Figure 2 . Mercury intrusion experiments show that the upper 


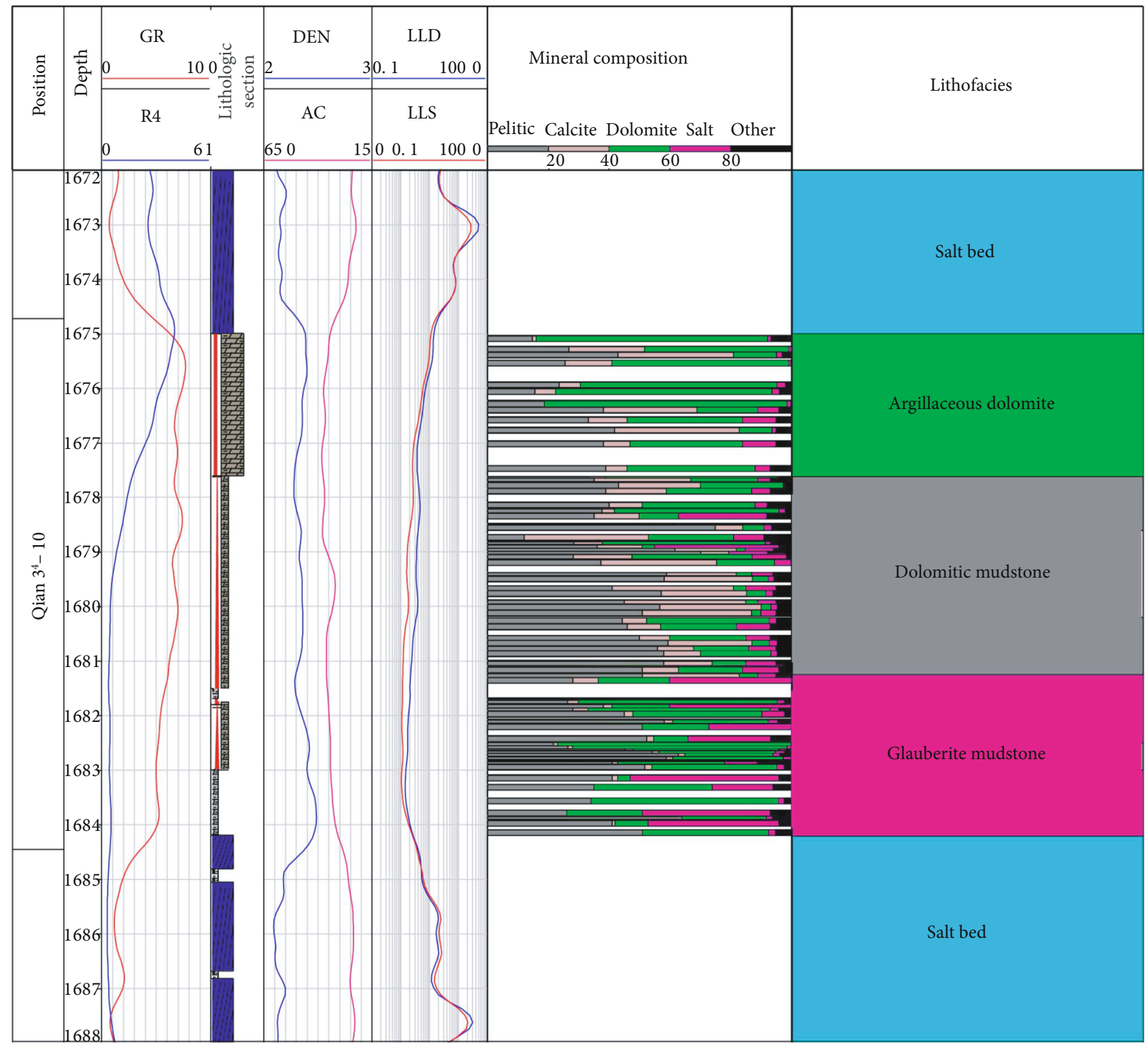

FIgURE 1: Sedimentary facies histogram of Qian $3^{4}-10$ cyclothem in the intersalt dolomite shale reservoir.

TABLE 1: Average pore throat radius of different lithofacies of Qian $3^{4}-10$ cyclothem in the intersalt dolomite shale reservoir.

\begin{tabular}{lccc}
\hline Lithofacies & Average median pressure $(\mathrm{MPa})$ & Average median pore throat radius $(\mathrm{nm})$ & Average pore throat radius $(\mathrm{nm})$ \\
\hline Argillaceous dolomite & 5.21 & 87.1 & 94 \\
Dolomite mudstone & 22.9 & 36.7 & 37.9 \\
Glauberite mudstone & 9.42 & 71.3 & 67.2 \\
\hline
\end{tabular}

carbon-rich laminated argillaceous dolomite facies (thickness of approximately $3-4 \mathrm{~m}$ ) has a high average pore throat radius $(>90 \mathrm{~nm})$ and relatively good physical properties. The dolomite mudstone facies in the middle and lower parts of the reservoir have poor physical properties, the median pressure of the mercury injection is high, and the average pore throat radius is less than $40 \mathrm{~nm}$.

\section{Microscopic Pore Structure and Salt Characteristics}

Scanning electron microscopy observations were performed on the pores using a Zeiss focused ion beam scanning helium ion microscope. The Gatan 691.CS argon ion thinning instrument was used for argon ion polished sampling. 


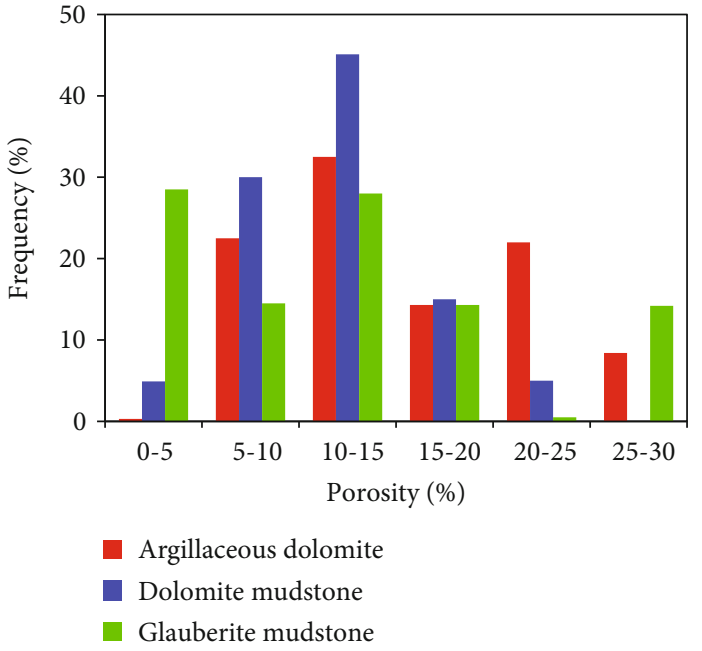

(a)

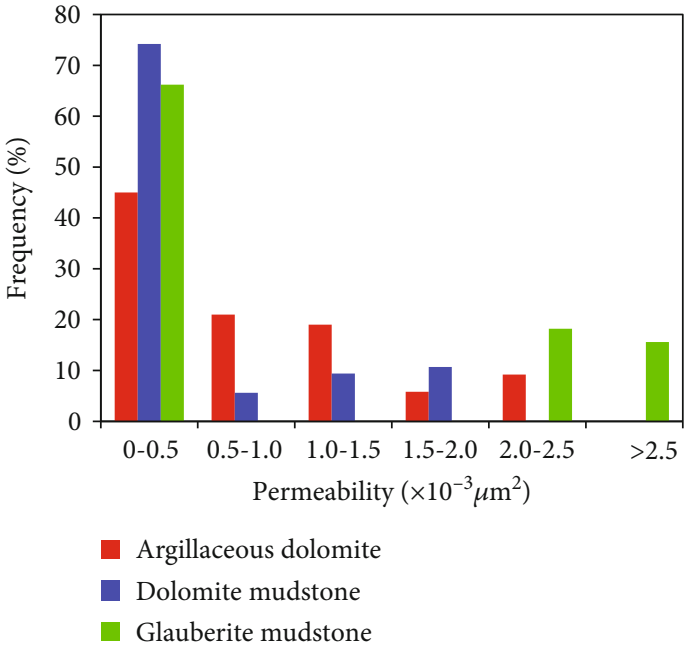

(b)

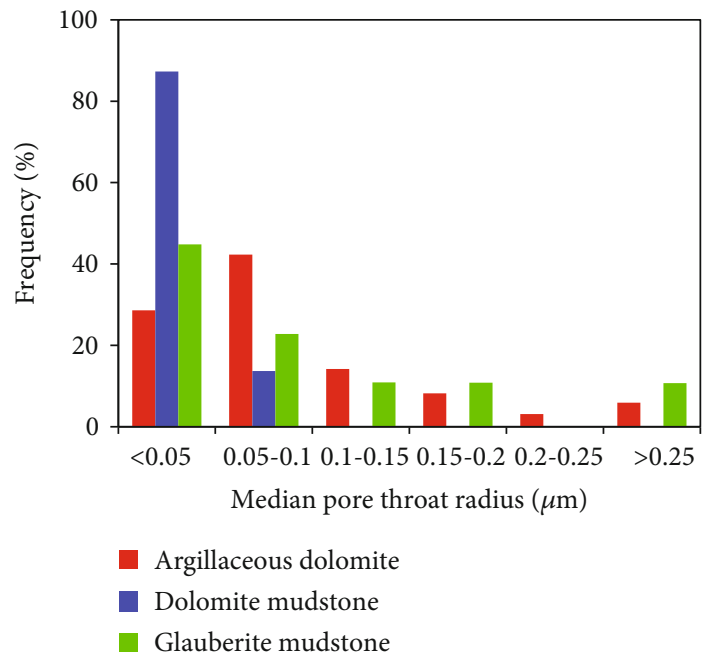

(c)

FIGURE 2: Spectrum statistics results of porosity and permeability of different lithologies.

The main steps include sample pregrinding, high-energy argon ion thinning pretreatment, surface deposition of a conductive film, gold coating treatment, and electron microscope observation. The surface of the argon ion polished sample is smooth, and the backscattered electron imaging used is suitable for observing the microstructure and morphology of the nanopores.

3.1. Microscopic Pore Structure. Dolomites are widely distributed in argillaceous dolomite, often with rhombohedral crystals, and the grains are mostly less than $5 \mu \mathrm{m}$ in size. It mainly develops dolomite and glauberite intergranular pores. The diameter of the dolomite intergranular pores is generally $0.5-10 \mu \mathrm{m}$, which are large intergranular pores supported by dolomite mineral lattice. The average pore diameter is nearly $2 \mu \mathrm{m}$, and the surface pore rate can reach $7.8 \%$, as shown in Figure 3(a). The dolomite intergranular pores are one of the important oil storage spaces in the intersalt shale oil reservoir. Dissolution pores are generally distributed with a pore diameter of approximately $0.5-9 \mu \mathrm{m}$ and a dissolution surface pore rate of around 5\%-20\%. They develop near the bedding plane and are also the main oil storage space. Most of the dissolution pores are effective pores, but some are filled with a large amount of salt particles, such as rock salt or glauberite, as shown in Figure 3(b). Second, a small number of intragranular pores are developed, including dolomite and quartz intragranular pores. The pore size is generally $5-200 \mathrm{~nm}$ with an average of $30 \mathrm{~nm}$, and the surface pore rate can reach up to $4.2 \%$. The dolomitic mud shale also develops intergranular pores of clustered pyrite, bedding joints, and diagenetic shrinkage joints, as shown in Figures 3(c) and 3(d).

The dolomite mudstone mainly develops intergranular pores of clay minerals and dolomite. The pore diameter is generally $0.5-6 \mu \mathrm{m}$ with an average of around $1 \mu \mathrm{m}$, and the surface pore rate can reach up to $6.1 \%$. Rock salt particles are scattered on the pore surface. The rock salt crystals have a good original shape and are tetragonal. The length of the single particles is slightly shorter at around $200 \mathrm{~nm}$. Clay minerals and dolomite intragranular pores are developed. The 


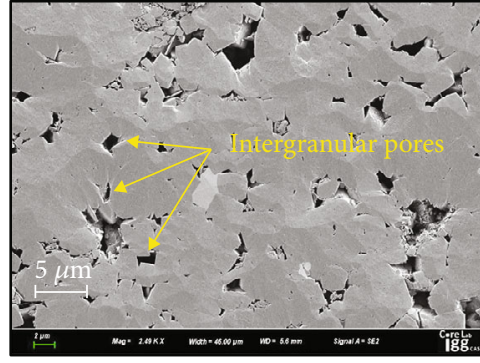

(a)

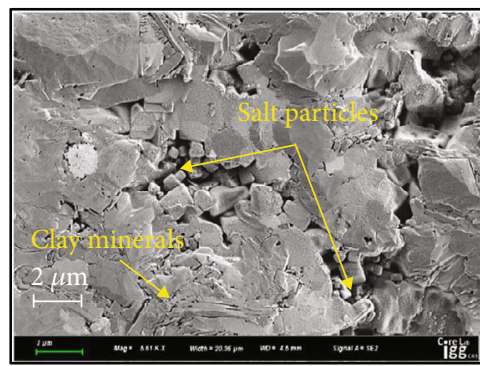

(c)

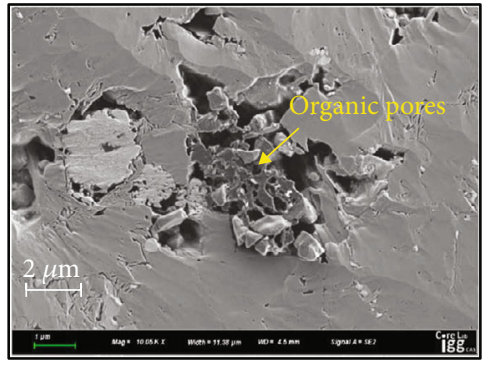

(e)

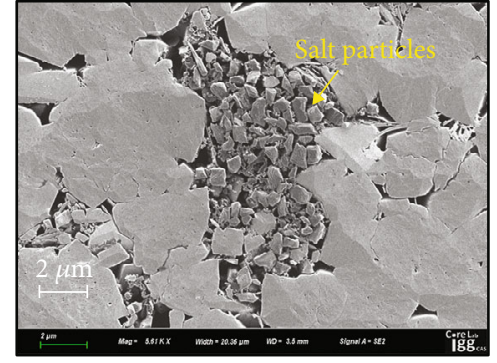

(b)

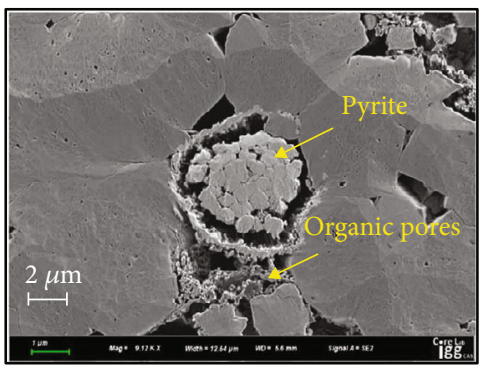

(d)

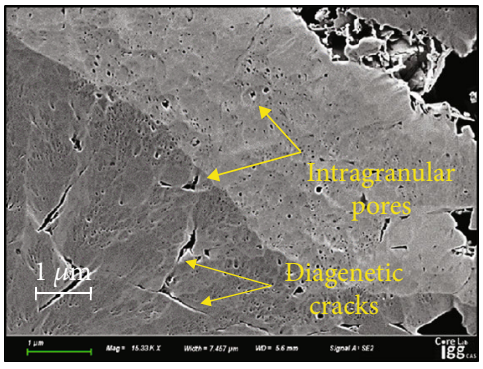

(f)

FIGURE 3: Original pore structure characteristics of intersalt dolomitic shale.

pore size is generally $5-200 \mathrm{~nm}$ with an average of around $50 \mathrm{~nm}$, and the surface pore rate can reach up to $3.1 \%$. Compared with argillaceous dolomite, the dolomite mudstone pores are less developed, and the pore size is relatively small, as shown in Figure 3(e).

In addition, a small number of organic pores that developed inside the pyrolysis asphalt are found in the dolomite mudstone. The pore morphology is mostly irregular, bubble-like, and elliptical. The pore size is $5-300 \mathrm{~nm}$, with an average of around $100 \mathrm{~nm}$, and the surface pore rate can reach up to $15 \%$, as shown in Figure 3(f). Secondary mineral particles with complete crystallization are usually developed in the edge or interior of the organic pores, and the pore volume usually accounts for $20 \%-50 \%$ of the total volume of organic particles with good pore connectivity.

3.2. Soluble Salt Minerals. The electron microscopy scanning results showed that the intersalt reservoir has microscopic salinity characteristics. Soluble salt minerals are widely distributed in the pores and cracks. The microscopic morphology of the reservoir salt particles consists of a single salt particle and a collection of salt particles. The intergranular pore size of the salt particles is less than $300 \mathrm{~nm}$. The salt aggregates can completely fill the pores and also block the cracks, resulting in poor pore connectivity of the reservoir and hindering fluid flow in the reservoir.

Moreover, the intersalt cloud shale also has macroscopic salinity characteristics. As can be seen by the naked eyes, the core rock sample is mixed with unequal rock salt and glauberite particles, and some cracks are also filled with salt minerals. The salt characteristics of shale samples are quantitatively described by micro-CT scanning technique. The results show that in the Qian $3^{4}-10$ cyclothem, few salt particles are present in the argillaceous dolomite layer and shale in the middle dolomite mudstone layer, mainly distributed between $1.3 \%$ and $3.8 \%$, as shown in Figures $4(\mathrm{a})$ and $4(\mathrm{~b})$. At the same time, the cracks are partially filled with sodium chloride particles and glauberite minerals. The glauberite mudstone near the salt layer has high salt content, and the volume ratio of the sodium chloride and glauberite particles is around $15.7 \%-21.81 \%$, as shown in Figure $4(\mathrm{c})$.

Fracturing practice shows that the salinity of the flowback fluid of the shale reservoir is generally high $[18,19]$. With the extension of the backflow time, the salinity of the flowback fluid keeps increasing, reaching up to $10 \times 10^{4} \mathrm{mg} \mathrm{L}^{-1}$, whereas the salinity of the slick water injected during fracturing is very low (approximately $1000 \mathrm{mg} \mathrm{L}^{-1}$ ) $[18,19]$. The salt ions in the flowback fluid are mainly derived from the 

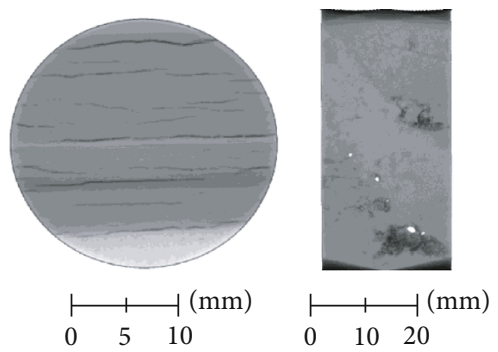

(a) Argillaceous dolomite

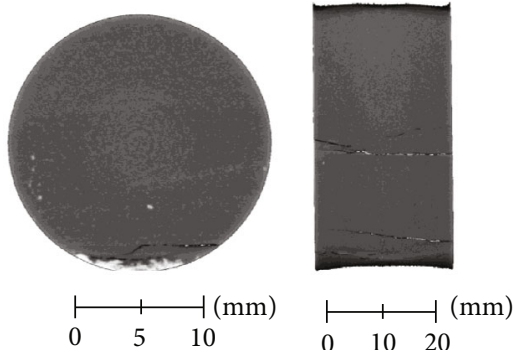

(b) Dolomite mudstone

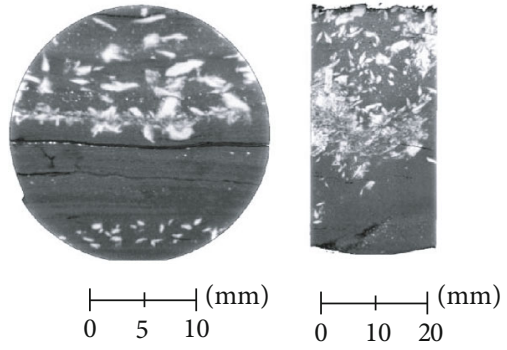

(c) Glauberite mudstone

FIgURE 4: Micro-CT scanning results of the core rock (white spots are salt particles).

dissolution of the shale's own minerals and the crystalline salts of the pore walls. When the fracturing fluid with low salinity enters the reservoir, the large difference in salinity between the fracturing fluid and the formation results in a remarkable chemical potential difference between them, which becomes the driving force for the low salinity liquid to enter the shale interior [20-22]. As for the intersalt dolomite shale reservoir, the interior has microscopic and macroscopic salinity properties, and the high-salinity difference will lead to a high chemical potential difference. After the fracturing fluid with low salinity infiltrates into the reservoir, it dissolves the salt minerals inside the reservoir continuously. Superficially, if the matrix and soluble salts in the fractures of the shale reservoir are dissolved, additional circulation channels can be obtained for reservoir oil and gas. This is also one of the main reasons for using low-viscosity slick water fracturing or water injection to increase shale oil production. However, further studies are needed to determine the specific effects of dissolution, migration, and recrystallization of soluble salt minerals on the physical properties of a reservoir.

\section{Effects of Different Fluid Types}

4.1. Sample Collection and Processing. The core samples are taken from the downhole cores of the Qian3 $3^{4}-10$ cyclothem at varying depths in the Qianjiang Depression, Jianghan Basin. As the intersalt shale is a typical stratified rock mass, the bedding surface is prone to open when exposed to water. However, factors such as the water solubility of salt rock can also contribute to this problem. Therefore, to avoid the opening of the bedding surface and dissolution of soluble minerals within the rock caused by hydraulic cutting, all samples in the experiment undergo anhydrous processing, and the samples are processed into a standard core column with a diameter of $2.54 \mathrm{~cm}$. Then, the side of the core is wrapped and sealed with epoxy resin, and only the two end faces of the core are in contact with the fluid when immersed.

4.2. Methods of Experiment. The shale sample is preplaced in a high-temperature and high-pressure reaction tank with a volume of $157 \mathrm{~mL}$ and evacuated. Then, fluid is injected into the reaction tank until the pressure becomes constant at $20 \mathrm{MPa}$, and the temperature in the incubator is kept constant at $80^{\circ} \mathrm{C}$. The experimental immersion fluid includes distilled water, $\mathrm{CO}_{2}\left(\mathrm{CO}_{2}\right.$ is in a supercritical state at $80^{\circ} \mathrm{C}$ and

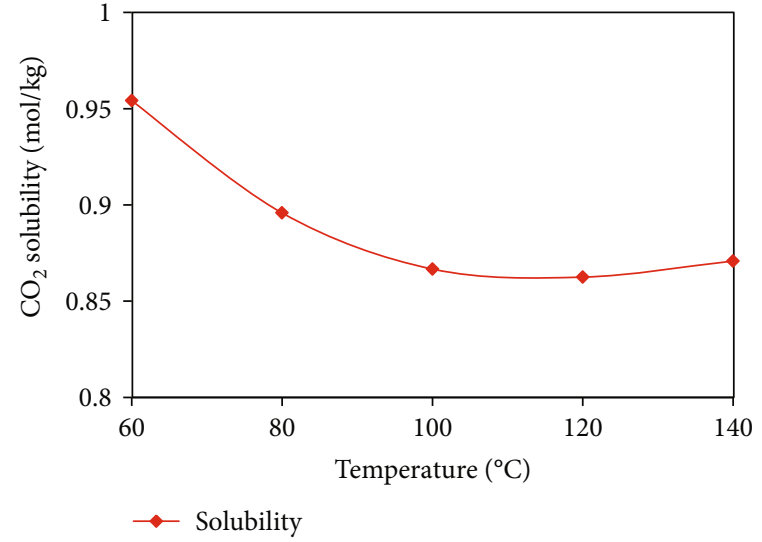

Figure 5: Solubility of $\mathrm{CO}_{2}$ in water $(20 \mathrm{MPa})$.

$20 \mathrm{MPa}$ ), and a liquid mixture of $\mathrm{CO}_{2}$ and distilled water (supercritical $\mathrm{CO}_{2}$ saturated solution). When the immersion fluid medium is a supercritical $\mathrm{CO}_{2}$ saturated solution, the immersion step differs from distilled water or pure $\mathrm{CO}_{2}$. First, $100 \mathrm{~mL}$ of distilled water is injected into the reaction tank. The shale sample is placed in an aqueous phase, evacuated, and heated at a constant temperature of $80^{\circ} \mathrm{C}$. Thereafter, the high-temperature and high-pressure reaction tank is charged with $\mathrm{CO}_{2}$ until the fluid pressure in the tank reaches $20 \mathrm{MPa}$.

After the shale samples are immersed under hightemperature and high-pressure conditions, the porosity and permeability of different shale samples are measured by using helium porosimetry and ultralow permeability meter (pulse attenuation method). Moreover, helium is used as the test gas.

4.3. Solubility of $\mathrm{CO}_{2}$. When supercritical $\mathrm{CO}_{2}$ is mixed with water, hydrogen ions are formed through ionization, which makes the solution acidic, as shown in formula (1). Related literatures show that the higher the pressure, the higher the solubility of $\mathrm{CO}_{2}$, the more hydrogen ions are ionized in the solution, and the lower the $\mathrm{pH}$ of the solution $[8,23,24]$. At the same time, the solubility of $\mathrm{CO}_{2}$ in water at different temperatures under $20 \mathrm{MPa}$ is measured, as shown in Figure 5. As seen in the figure, with the increase in temperature, the solubility of $\mathrm{CO}_{2}$ in water decreases and tends to be stable when the temperature is greater than $100^{\circ} \mathrm{C}$ :

$$
\mathrm{CO}_{2}+\mathrm{H}_{2} \mathrm{O} \longrightarrow \mathrm{H}^{+}+\mathrm{HCO}_{3}^{-}
$$




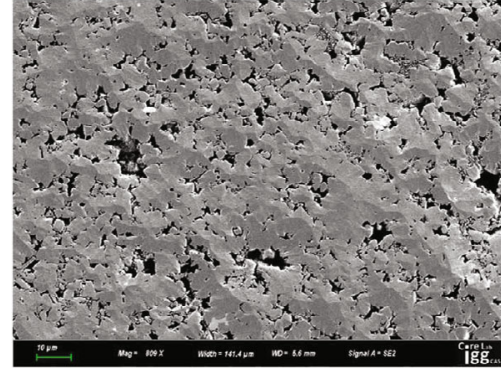

(a)

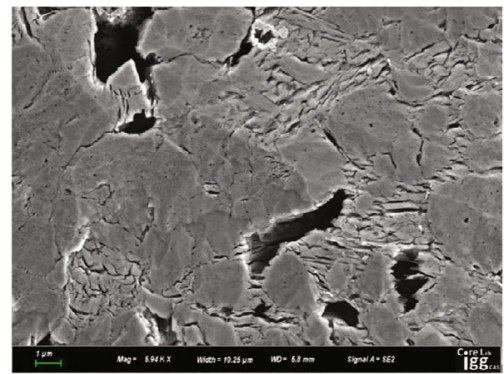

(c)

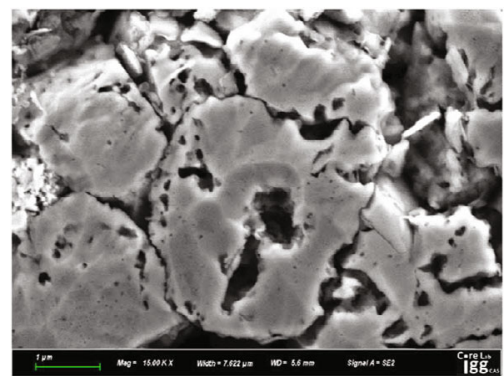

(e)

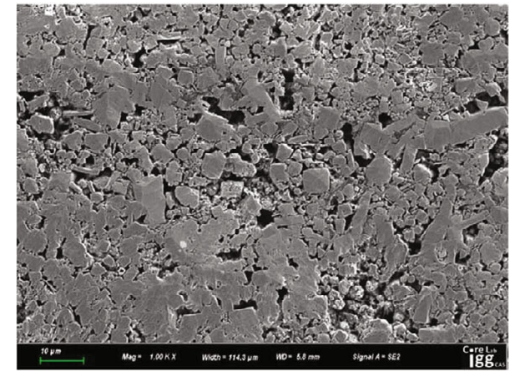

(b)

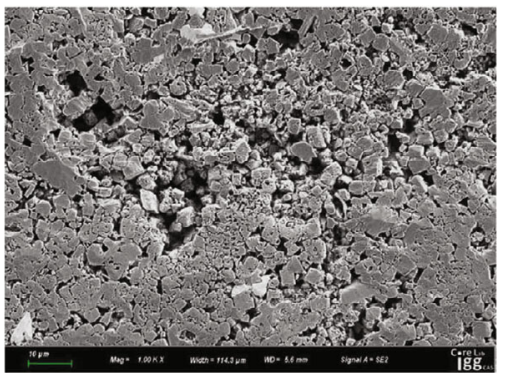

(d)

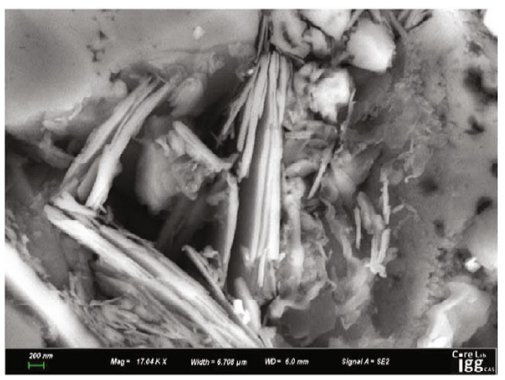

(f)

FIGURE 6: Microscopic pore structure changes before and after the interaction of different fluids. (a) Pores of muddy dolomite are increased, and salt minerals migrate (supercritical $\mathrm{CO}_{2}$ ). (b) Salt minerals are dissolved (distilled water). (c) Clay mineral expansion occurs (distilled water). (d) Pores are dissolved, causing caves (supercritical $\mathrm{CO}_{2}$ saturated solution). (e) Dolomite particles are dissolved, causing dissolved pores (supercritical $\mathrm{CO}_{2}$ saturated solution). (f) Clay is released, and particle migration occurs (supercritical $\mathrm{CO}_{2}$ saturated solution).

For intersalt shale reservoirs, active $\mathrm{H}^{+}$and $\mathrm{HCO}_{3}^{-}$ interact with carbonates, such as calcite and dolomite, to dissolve carbonate rocks:

$$
\begin{gathered}
\mathrm{CaCO}_{3}+\mathrm{H}^{+} \longrightarrow \mathrm{Ca}^{2+}+\mathrm{HCO}_{3}^{-} \\
\mathrm{CaMg}\left(\mathrm{CO}_{3}\right)_{2}+2 \mathrm{H}^{+} \longrightarrow \mathrm{Ca}^{2+}+\mathrm{Mg}^{2+}+2 \mathrm{HCO}_{3}^{-}
\end{gathered}
$$

$\mathrm{H}^{+}$and $\mathrm{HCO}_{3}^{-}$can also interact with the feldspar minerals inside the reservoir. Aside from causing dissolution and sedimentation of silicate, they can also form kaolinite:

$$
2 \mathrm{KAlSi}_{3} \mathrm{O}_{8}+2 \mathrm{H}^{+}+9 \mathrm{H}_{2} \mathrm{O} \longrightarrow 2 \mathrm{~K}^{+}+4 \mathrm{H}_{4} \mathrm{SiO}_{4}+\mathrm{Al}_{2} \mathrm{SiO}_{5}(\mathrm{OH})_{4}
$$

$$
\begin{aligned}
\mathrm{NaAlSi}_{3} \mathrm{O}_{3} & +\mathrm{CO}_{2}+5.5 \mathrm{H}_{2} \mathrm{O} \longrightarrow \mathrm{Na}^{+}+\mathrm{HCO}_{3}^{-}+2 \mathrm{H}_{4} \mathrm{SiO}_{4} \\
& +0.5 \mathrm{Al}_{2} \mathrm{SiO}_{5}(\mathrm{OH})_{4}
\end{aligned}
$$

Therefore, the interaction of $\mathrm{CO}_{2}$-water-reservoir rocks will lead to the dissolution of reservoir rocks and the formation of sediments, which will directly result in the change of pore structure and permeability of reservoirs.

\subsection{Results and Analysis of the Experiment}

4.4.1. Changes in the Microscopic Pore Structure. Under the conditions of $80^{\circ} \mathrm{C}$ and $20 \mathrm{MPa}$, the shale samples are immersed in distilled water, supercritical $\mathrm{CO}_{2}$, and supercritical $\mathrm{CO}_{2}$ saturated solution. Then, microscopic pore scanning electron microscopy is conducted to compare the microstructure changes in the intersalt cloud shale before and after the fluid action. The results are shown in Figure 6.

For argillaceous dolomite samples, some of the pores are filled with many salt crystals without treatment, as shown in Figure 3(a). The filled salt minerals occupy most of the fluid passages, hindering fluid migration. After immersing in supercritical $\mathrm{CO}_{2}$, the surface pore rate reaches $9.1 \%$, as shown in Figure 6(a). This result may be due to the expansion 


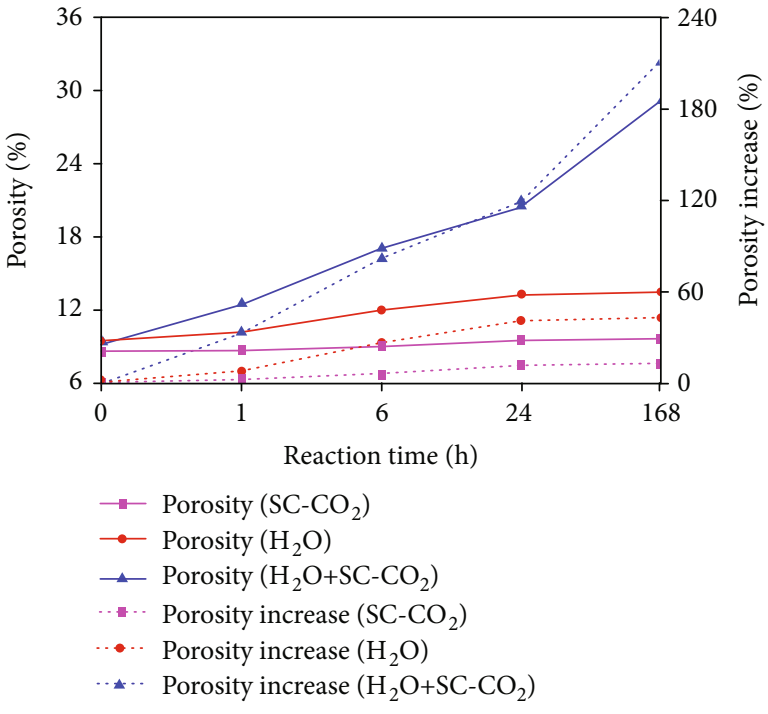

(a) Argillaceous dolomite

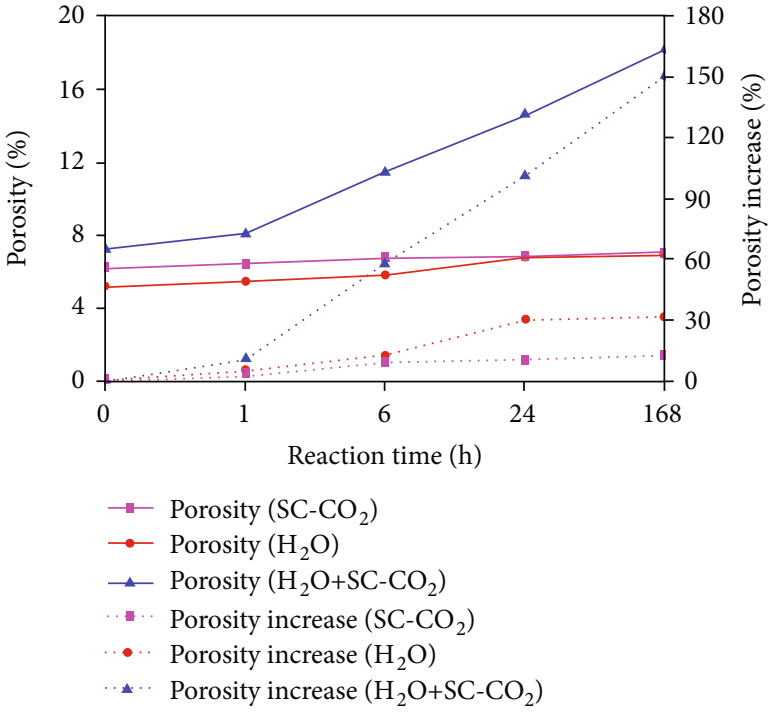

(b) Dolomite mudstone

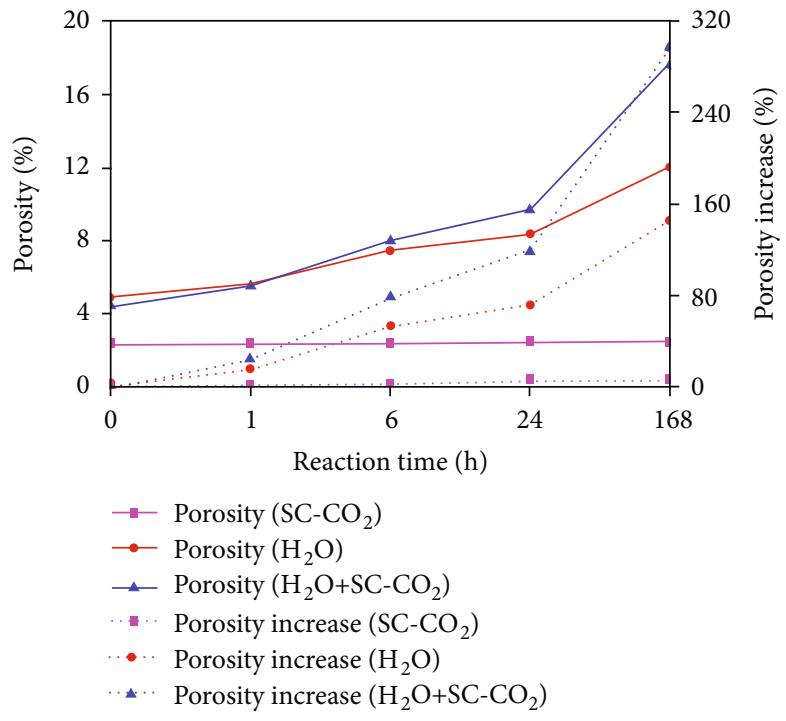

(c) Glauberite mudstone

Figure 7: Change of porosity after immersion in fluid at different times.

of $\mathrm{CO}_{2}$. On the one hand, the pore throat radius increases and the effective stress decreases due to the volume expansion of $\mathrm{CO}_{2}$. On the other hand, the $\mathrm{CO}_{2}$ expansion affects and disperses the collection of salt particles in the pore channels into salt particles, thereby dredging pores and reducing the flow resistance of the reservoir fluid. However, under the reservoir conditions, the salt minerals still remain in the reservoir and occupy the flow channels of the reservoir fluid.

When immersed in distilled water, the salt crystals in the pores dissolve, and the pore channels expand, significantly increasing the surface pore rate (around 40\%) and greatly improving pore connectivity, as shown in Figure 6(b). However, distilled water weakens the cohesive force between the rock mineral particles, which loosens the rocks and even produces microcracks. In addition, the clay mineral undergoes hydration expansion under the action of water, as shown in Figure 6(c). However, due to the low clay mineral content of the intersalt shale reservoir, the hydration of clay minerals has minimal effect on the shale skeleton or pore structure.

When the shale sample is immersed in a supercritical $\mathrm{CO}_{2}$ saturated solution, the saturated solution has the greatest impact on the micropore structure of shale. First, distilled water can dissolve salt, and the pore channels are enlarged when salt crystals dissolve inside the pore channels. In addition, when supercritical $\mathrm{CO}_{2}$ dissolves in distilled water, it will produce a weak acid that will dissolve the cement and mineral components of the rock particles, thereby greatly increasing the pore radius and even producing the dominant channel of the acid-rock reaction. The surface pore rate can reach up to $23.6 \%$, as shown in Figure 6(d). Second, the weak acid solution will dissolve the skeleton particles, resulting in dissolved pores with a diameter of $50-100 \mathrm{~nm}$ inside the 


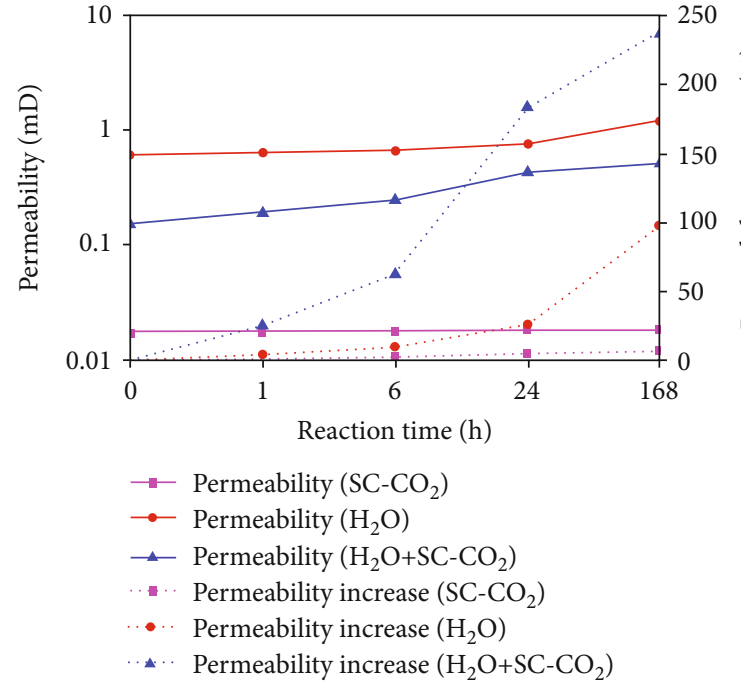

(a) Argillaceous dolomite

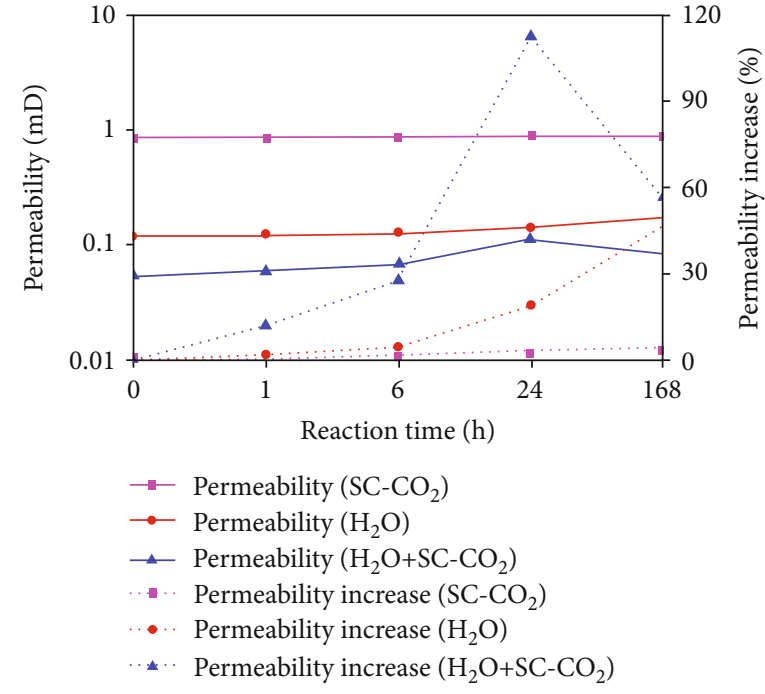

(b) Dolomite mudstone

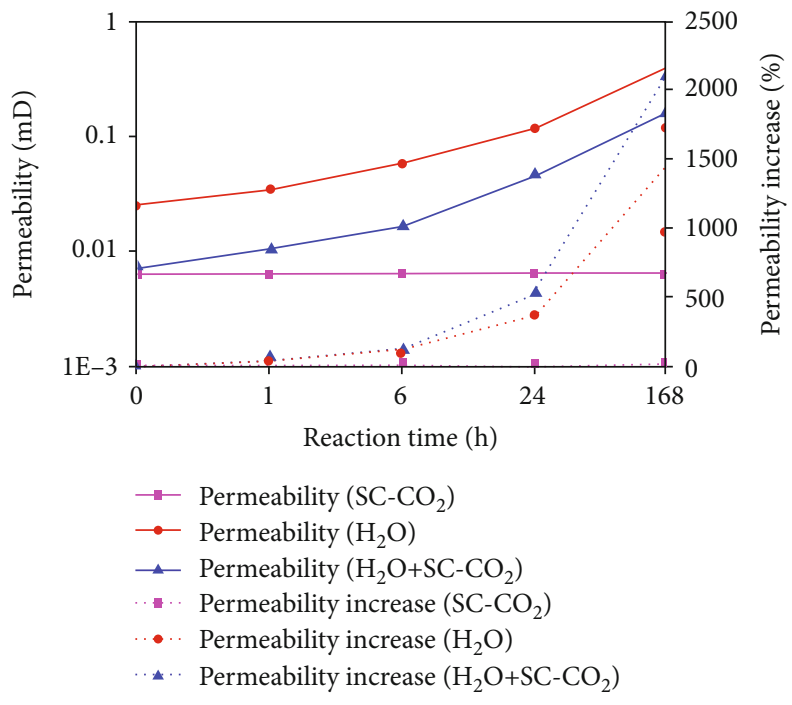

(c) Glauberite mudstone

Figure 8: Change of permeability after immersion in fluid at different times.

particles, as shown in Figure 6(e). The saturated solution destroys the stability of the clay minerals and causes the dissolution of the cement of the skeleton particle, leading to the increase of intergranular pores and considerable migration of clay particles, as shown in Figure 6(f).

4.4.2. Change of Porosity. Figure 7 shows the results of porosity change of the shale samples after immersing in supercritical $\mathrm{CO}_{2}$, distilled water, and supercritical $\mathrm{CO}_{2}$ saturated solution at $20 \mathrm{MPa}$ and $80^{\circ} \mathrm{C}$.

The results of the experiment show that the porosity increased at varying degrees after immersing the samples in different fluids. The supercritical $\mathrm{CO}_{2}$ saturated solution obtained the largest increase in porosity. The salt solution effect of distilled water combined with the dissolution effect of the weak acid generated by the dissolution of supercritical $\mathrm{CO}_{2}$ in water will greatly expand the pore and increase the pore volume. The porosity of argillaceous dolomite and glauberite mudstone with high total content of salt minerals and carbonates increased by $210.7 \%$ and $296.7 \%$, respectively, after immersion for $168 \mathrm{~h}$. The pore-enlarging effect of distilled water was mainly derived from the dissolution of salt minerals. The effect was most obvious in the glauberite mudstone with high salt content. The porosity of argillaceous dolomite and dolomite mudstone with lower salt mineral content increased by $43 \%$ and $31.9 \%$, respectively, after immersion in distilled water for $168 \mathrm{~h}$. By contrast, the pore-enlarging effect of supercritical $\mathrm{CO}_{2}$ was relatively small, and the porosity of different samples increased by approximately $6.0 \%$ to $13.2 \%$ after $168 \mathrm{~h}$ immersion.

4.4.3. Change of Permeability. After immersion in different fluids, an ultralow permeability meter is used to measure the change in permeability of the shale samples over time. The results are shown in Figure 8. 


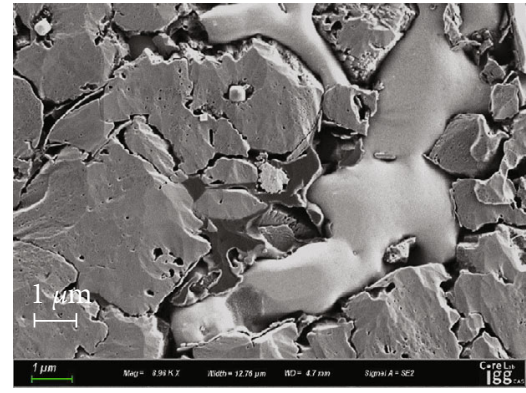

(a)

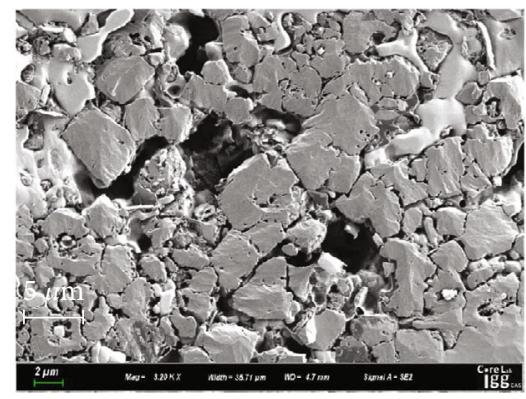

(c)

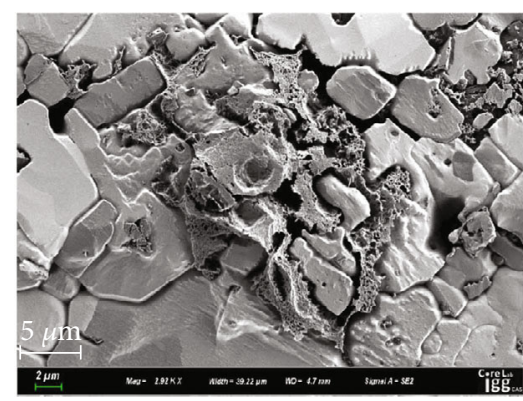

(e)

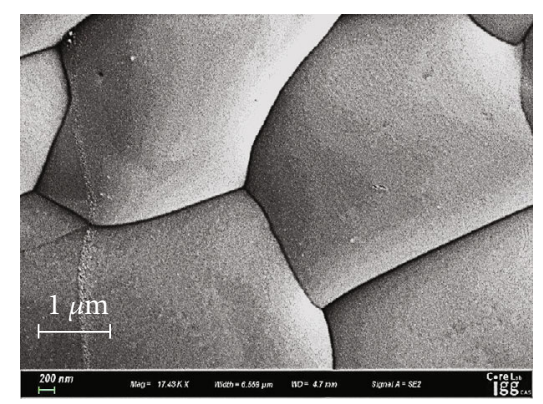

(b)

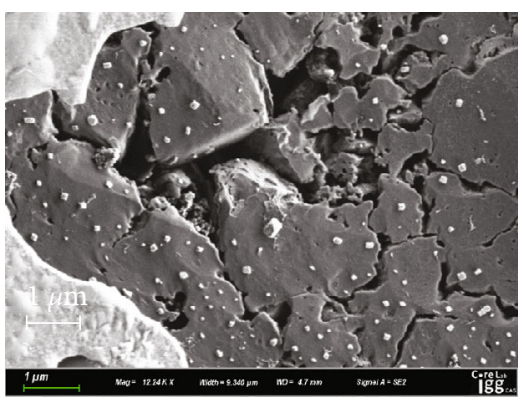

(d)

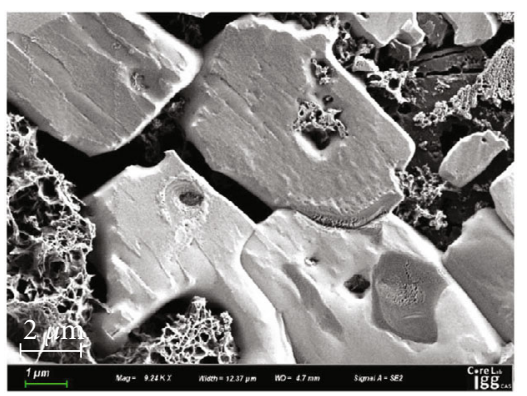

(f)

FIGURE 9: Pore microstructure changes after static evaporation salting out. (a) Clumps of superimposed growth morphology of salt crystals; (b) densely packed salt crystals with no internal permeability; (c) pores partially filled with salt crystals; (d) single-salt-particle dispersion morphology; (e, f) surface-attached layered or flocculent growth morphology of salt crystals.

As can be seen from the figure, the effect of supercritical $\mathrm{CO}_{2}$ on permeability improvement is not obvious. For the argillaceous dolomite samples with relatively good porosity and permeability, the permeability increases by $13.7 \%$ through flushing the salt crystal minerals and dredging the pore channels. For the glauberite mudstone samples, the permeability only changes by $4.2 \%$ due to its small internal pores that are mostly blocked by salt minerals. The permeability of distilled water is greatly improved by dissolving the salt minerals in the pores. After immersion for $168 \mathrm{~h}$, the permeabilities of the argillaceous dolomite and dolomite samples increase by $97.6 \%$ and $46.2 \%$, respectively. By contrast, the permeability of glauberite mudstone samples with high salt minerals increases by $14.7 \%$ after immersion for $168 \mathrm{~h}$. Therefore, the better the initial porosity and permeability conditions, the greater the salt content and the increase in permeability. When the supercritical $\mathrm{CO}_{2}$ is dissolved in distilled water, the weak acid dissolves and expands the pores, which then improves interporosity connectivity, enlarges the range of water-salt-rock action, and strengthens the salt solution of distilled water. The permeability of the glauberite mudstone minerals increases by 21.1 times after immersion in supercritical $\mathrm{CO}_{2}$ saturated solution for $168 \mathrm{~h}$.

\section{Effects of Recrystallization of Salt Minerals}

During the mining process, due to changes of formation temperature and pressure in and near the wellbore, the solubility of the salt minerals changes, causing the precipitation of salt minerals and salt crystallization. Then, salt crystallization will lead to damage near the wellbore reservoir. The static evaporation salting-out method is used to simulate the salt crystallization phenomenon in the formation so as to evaluate the damage degree of salt crystallization on the porosity and permeability of the intersalt shale oil reservoir. The specific steps are as follows: (1) under the conditions of $80^{\circ} \mathrm{C}$ and $20 \mathrm{MPa}$, the shale sample is placed in a saturated sodium chloride solution for $24 \mathrm{~h}$ using a high-temperature and high-pressure reactor; (2) the shale immersed in the saturated sodium chloride solution is heated in an oven at a constant temperature $60^{\circ} \mathrm{C}$ and evaporated to constant weight; and (3) the morphology and microscopic 


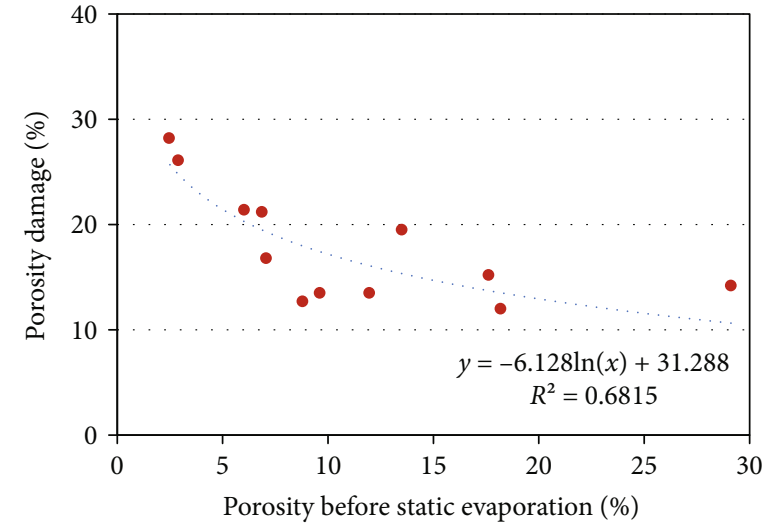

(a)

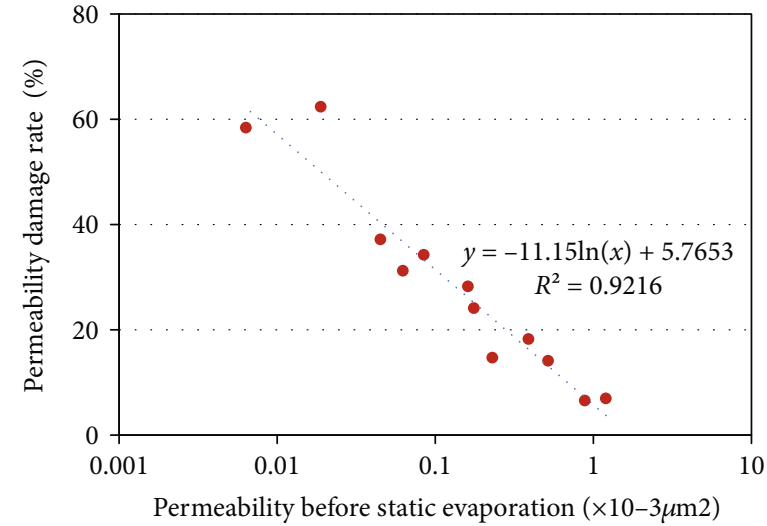

(b)

FIGURE 10: Effects of salt precipitation on the porosity and permeability of intersalt dolomitic shale.

distribution of salt crystals are observed under scanning electron microscopy to determine the effect on the porosity and permeability of the intersalt shale.

\subsection{Morphology and Microscopic Distribution of Salt Crystal.} Scanning electron microscopy observation of salt shale after salt crystallization shows three main forms of salt crystals, including clumps of superimposed growth morphology of intergranular pore/seam filling type, surface-attached layered or flocculent growth morphology, and single-particle dispersion morphology, as shown in Figure 9.

The filling-type agglomerated crystalline salt usually aggregates in the dominant channel with good evaporation environment. These channels generally have large pore size and good connectivity because the fluid saturation in the large pores is usually high and the large pore size also provides a good evaporation environment for the liquid [25-27]. The salt crystals are stably stacked in the large pores and gradually fill the entire pores. However, these filled salt crystals are densely packed and have no internal permeability, as shown in Figure 9(b). Therefore, the filling of the cluster salt crystals may partially cause the dominant pores to fail, as shown in Figure 9(c). At the corners of pores or on the surfaces of rocks, scattered regular single-crystal crystalline salts with a length of tens to hundreds of nanometers are present, as shown in Figures 9(a) and 9(d). Given the small particle size, such salt crystals tend to migrate and block small pores.

When the flow and evaporation environments of the tunnel are relatively poor, irregular flocculated or layered crystals attached to the surface of rock particles are generated due to unstable salt crystal deposition (Figures 9(d)-9(f)). On the one hand, the layered adhesion and flocculation of the salt crystals will make the pore flow channel narrower. On the other hand, the flocculent salt crystals are easy to disperse, accumulate, and block the pore due to the lack of framework support.

5.2. Influence on Porosity and Permeability. The microscopic scanning results show that salt crystallization will occupy a certain reservoir pore space and block the shale pore channels. By measuring the changes of shale porosity and permeability before and after static evaporation salting-out experiments, the salt crystals will lead to the decrease of porosity and permeability of shale. The average porosity and permeability decreased by $17.8 \%$ and $37.5 \%$, respectively, as shown in Figure 10. The smaller the porosity and permeability of the shale, the greater the damage of salt crystals to the porosity and permeability. This is due to the small pore throat of rocks with low permeability, most of which contain small pores or micropores. These micropores are easily blocked by fine salt crystals, so the permeability is drastically lowered. For rocks with high permeability, most of the pore channels are relatively large and are not easily blocked by salt crystals. In addition, the dispersed crystalline salt particles are more likely to migrate in cores with better permeability [26-28]. Therefore, the permeability of the shale sample with high permeability will slightly decrease after the salt crystallizes.

\section{Discussion}

With low water saturation and high salt content in pores, the formation water in the intersalt dolomite shale reservoir mainly exists in the form of salt crystal water. The salt crystals will block the pore channels, reduce the connectivity between pores, and increase flow resistance. Water-based fracturing fluids can greatly increase the porosity and permeability of reservoirs by dissolving the salt minerals in the matrix. The salt minerals are dissolved after contact with water, especially in the glauberite mudstone layer near the salt layer. Then, the rock porosity and permeability will be greatly improved. When the salt minerals are dissolved, they will migrate to the fracture and bottom of the well in the form of high-salinity water. Under the influence of temperature and pressure, high-salinity water recrystallizes and gradually blocks the matrix, cracks, and wellbore. At this point, the water extrusion process can be adopted to restore the production capacity of the reservoir by dissolving the salt minerals. However, the water injected in a later stage continuously acts on the glauberite mudstone layer and strengthens its permeability, thereby providing unfavorable conditions for the dissolution of the salt layer at the top of the reservoir and the migration of many salt minerals. 
Supercritical $\mathrm{CO}_{2}$ fracturing can avoid the problems caused by the dissolution, migration, and recrystallization of salt minerals due to water-based fracturing fluids. At the same time, supercritical $\mathrm{CO}_{2}$ fracturing increases the complexity of hydraulic fractures and improves the fluidity of the mixed phase. However, the results of microscopic scanning observation and pore infiltration parameter test show that the salt content and pore connectivity of intersalt shale reservoirs are poor. Although supercritical $\mathrm{CO}_{2}$ can disperse the salt particles, dredge the channels, and enlarge the pores due to expansion, its overall ability to change the structure and permeability of the pores is still weak. Therefore, it cannot meet the requirements of economic development for transformation effect by only using the supercritical $\mathrm{CO}_{2}$ for the transformation of intersalt shale reservoirs.

At present, the fracturing technology combining $\mathrm{CO}_{2}$ with water-based fracturing fluid has become an emerging technology for unconventional oil and gas development. For the intersalt shale oil reservoir, the supercritical $\mathrm{CO}_{2}$ composite fracturing technology can reduce the amount of water-based fracturing fluid and the considerable dissolution and migration of salt minerals. At the same time, after the $\mathrm{CO}_{2}$-water-shale interaction, the pore circulation channel is enlarged, and porosity and permeability are improved. To a certain extent, the damage of salt crystals to the physical properties of the reservoir near the wellbore is reduced. Therefore, the $\mathrm{CO}_{2}$ composite fracturing technology combines the salt dissolution effect of waterbased fracturing fluid and the unique effect in production increase of $\mathrm{CO}_{2}$, which may cause effective long-term development of intersalt shale oil reservoirs. However, further research needs to be conducted on how to optimize the amount and proportion of $\mathrm{CO}_{2}$ and water-based fracturing fluid based on the physical damage law of the reservoir under the interaction of fluid-rock-salt in the intersalt dolomite shale reservoir.

\section{Conclusion}

(1) The intersalt dolomite shale reservoir has microscopic and macroscopic saliferous characteristics, which lead to poor pore connectivity of the reservoir and hinder the flow of reservoir fluid. Distilled water can enlarge the flow passage by dissolving soluble salt minerals inside the reservoir. However, the dissolution and migration of many salt crystals will cause problems for later production

(2) During the mining process, salt minerals are precipitated, and salt crystals are formed due to changes in formation temperature and pressure in the wellbore and near the well. Salt crystals will occupy a certain pore space and block the pore channel. The smaller the porosity of the shale and the lower the permeability, the greater the damage of salt crystals to the pores

(3) Supercritical $\mathrm{CO}_{2}$ disperses the salt particles, dredges the channels, and slightly enlarges the pores by expansion, but the overall ability to change the pore structure and connectivity is still weak. By using supercritical $\mathrm{CO}_{2}$ to transform the intersalt shale reservoir, the problems caused by salt dissolution and recrystallization can be avoided. However, supercritical $\mathrm{CO}_{2}$ cannot meet the requirement of economic development for the transformation effect

(4) When supercritical $\mathrm{CO}_{2}$ is dissolved in distilled water, it will produce a weak acid, which erodes the cement and the mineral components of the rock particles, greatly increasing the radius of the channel. At the same time, by reducing the amount of waterbased fracturing fluid and increasing the porosity and permeability of the matrix, the cycle of salt plugging caused by the massive migration of salt minerals will be reduced, which is conducive to extending the effective period of increased production

\section{Data Availability}

The data used to support this study are included within the article.

\section{Conflicts of Interest}

The authors declare that they have no conflicts of interest.

\section{Acknowledgments}

This paper was support by the Major National Science and Technology Projects of China (No. 2017ZX05049003-05).

\section{References}

[1] Z. Shanwen, "Thinking and practice of tertiary oil and gas exploration of maturing region in eastern China: a case study of Jiyang depression," Acta Petrolei Sinica, vol. 33, no. s1, pp. 53-62, 2012.

[2] M. L. Sinal and G. Lancaster, "Liquid $\mathrm{CO}_{2}$ fracturing: advantages and limitations," Journal of Canadian Petroleum Technology, vol. 26, no. 5, pp. 26-30, 1987.

[3] T. Ishida, Q. Chen, Y. Mizuta, and J. C. Roegiers, "Influence of fluid viscosity on the hydraulic fracturing mechanism," Journal of Energy Resources Technology, vol. 126, no. 3, pp. 190200, 2004.

[4] B. C. Nuttall, C. Eble, R. M. Bustin, and J. A. Drahovzal, Analysis of Devonian black shales in Kentucky for potential CO2 sequestration and enhanced natural gas production, Kentucky Geological Survey, USA, 2005.

[5] A. Kizaki, H. Tanaka, K. Ohashi, K. Sakaguchi, and K. Matsuki, "Hydraulic fracturing in Inada granite and Ogino tuff with super critical carbon dioxide," in ISRM Regional Symposium-7th Asian Rock Mechanics Symposium, International Society for Rock Mechanics and Rock Engineering, 2012.

[6] Z. Bennour, T. Ishida, Y. Nagaya et al., "Crack extension in hydraulic fracturing of shale cores using viscous oil, water, and liquid Carbon Dioxide," Rock Mechanics and Rock Engineering, vol. 48, no. 4, pp. 1463-1473, 2015. 
[7] A. B. Yost, R. L. Mazza, and J. B. Gehr, "CO2/Sand fracturing in devonian shales," in SPE Eastern Regional Meeting, Society of Petroleum Engineers, 1993.

[8] Y. Zou, S. Li, X. Ma, S. Zhang, N. Li, and M. Chen, "Effects of $\mathrm{CO}_{2}$-brine-rock interaction on porosity/permeability and mechanical properties during supercritical- $\mathrm{CO}_{2}$ fracturing in shale reservoirs," Journal of Natural Gas Science and Engineering, vol. 49, pp. 157-168, 2018.

[9] R. Tudor, C. Vozniak, W. Peters, and M. Banks, "Technical advances in liquid $\mathrm{CO}_{2}$ fracturing," in Annual Technical Meeting, Petroleum Society of Canada, Calgary, Alberta, 1994.

[10] S. Fischer, A. Liebscher, and $\mathrm{M}$. Wandrey, " $\mathrm{CO}_{2}$-brine-rock interaction - First results of long-term exposure experiments at in situ P-T conditions of the Ketzin $\mathrm{CO}_{2}$ reservoir," Chemie der Erde-Geochemistry, vol. 70, no. S3, pp. 155-164, 2010.

[11] M. Alam, M. Hjuler, H. Christensen, and I. Fabricius, "Petrophysical and rock-mechanics effects of $\mathrm{CO}_{2}$ injection for enhanced oil recovery: Experimental study on chalk from South Arne field, North Sea," Journal of Petroleum Science and Engineering, vol. 122, pp. 468-487, 2014.

[12] Q. Lyu, P. Ranjith, X. Long, and B. Ji, "Experimental investigation of mechanical properties of black shales after $\mathrm{CO}_{2}$ water-rock interaction," Materials, vol. 9, no. 8, p. 663, 2016.

[13] Y. Lu, X. Ao, J. Tang, Y. Jia, X. Zhang, and Y. Chen, "Swelling of shale in supercritical carbon dioxide," Journal of Natural Gas Science and Engineering, vol. 30, pp. 268-275, 2016.

[14] H. Yin, J. Zhou, X. Xian et al., "Experimental study of the effects of sub- and super-critical $\mathrm{CO}_{2}$ saturation on the mechanical characteristics of organic-rich shales," Energy, vol. 132, pp. 84-95, 2017.

[15] C. G. Huang, X. L. Ni, and X. M. Ma, "Petroleum and gas enrichment pattern and major controlling factors of stable and high production of tight lacustrine carbonate rock reservoirs: a case of the Yingxi area in Qaidam Basin," Journal of Northwest University (Natural Science Edition), vol. 47, no. 5, pp. 724-738, 2017.

[16] J. M. Hunt, "Generation and Migration of Petroleum from Abnormally Pressured Fluid Compartments (1)," AAPG Bulletin, vol. 74, no. 1, pp. 1-12, 1990.

[17] C. G. Huang, J. Y. Yuan, G. R. Tian, L. R. Wu, X. Pan, and Y. Y. Hui, "The geochemical characteristics and formation mechanism of the Eocene lacustrine dolomite reservoirs in the western Qaidam," Earth Science Frontiers, vol. 23, no. 3, pp. 230-242, 2016.

[18] F. Wang and Z. Pan, "Numerical simulation of chemical potential dominated fracturing fluid flowback in hydraulically fractured shale gas reservoirs," Petroleum Exploration and Development, vol. 43, no. 6, pp. 971-977, 2016.

[19] L. Yang, H. Ge, X. Shi et al., "The effect of microstructure and rock mineralogy on water imbibition characteristics in tight reservoirs," Journal of Natural Gas Science \& Engineering, vol. 34, pp. 1461-1471, 2016.

[20] H. K. Ge, L. Yang, Y. H. Shen et al., "Experimental investigation of shale imbibition capacity and the factors influencing loss of hydraulic fracturing fluids," Petroleum Science, vol. 12, no. 4, pp. 636-650, 2015.

[21] P. Fakcharoenphol, B. Kurtoglu, H. Kazemi, S. Charoenwongsa, and Y.S. Wu, "The effect of osmotic pressure on improve oil recovery from fractured shale formations," in SPE unconven- tional resources conference, Society of Petroleum Engineers, 2014.

[22] T. Zhou, S. Zhang, L. Yang, X. Ma, Y. Zou, and H. Lin, “Experimental investigation on fracture surface strength softening induced by fracturing fluid imbibition and its impacts on flow conductivity in shale reservoirs," Journal of Natural Gas Science \& Engineering, vol. 36, pp. 893-905, 2016.

[23] R. Shiraki and T. L. Dunn, "Experimental study on water-rock interactions during $\mathrm{CO}_{2}$ flooding in the Tensleep Formation, Wyoming, USA," Applied Geochemistry, vol. 15, no. 3, pp. 265-279, 2000 .

[24] Z. H. Duan and R. Sun, "An improved model calculating $\mathrm{CO}_{2}$ solubility in pure water and aqueous $\mathrm{NaCl}$ solutions from 273 to $533 \mathrm{~K}$ and from 0 to 2000 bar," Chemical Geology, vol. 193, pp. 257-271, 2003.

[25] T. Yong, D. Zhimin, and J. Hongmei, "Reservoir damages caused by formation-water salt precipitation in high-pressure and high-temperature gas reservoirs," Acta Petrolei Sinica, vol. 33, no. 5, pp. 859-863, 2012.

[26] C. Guodong, R. Shaoran, L. Zhang et al., "Formation water evaporation induced salt precipitation and its effect on gas production in high temperature natural gas reservoirs," Petroleum Exploration and Development, vol. 43, no. 5, pp. 749-757, 2016.

[27] A. H. Alizadeh, M. Akbarabadi, E. Barsotti, M. Piri, N. Fishman, and N. Nagarajan, "Salt Precipitation in UltraTight Hydrocarbon Reservoir Rocks: A Multi-Scale Experimental Study," in Unconventional Resources Technology Conference, Austin, Texas, 24-26 July 2017, pp. 2267-2273, Society of Exploration Geophysicists, American Association of Petroleum Geologists, Society of Petroleum Engineers, 2017.

[28] M. Bai, A. Bouhroum, F. Civan, and J. C. Roegiers, "Improved model for solute transport in heterogeneous porous media," Journal of Petroleum Science \& Engineering, vol. 14, no. 1-2, pp. 65-78, 1995. 

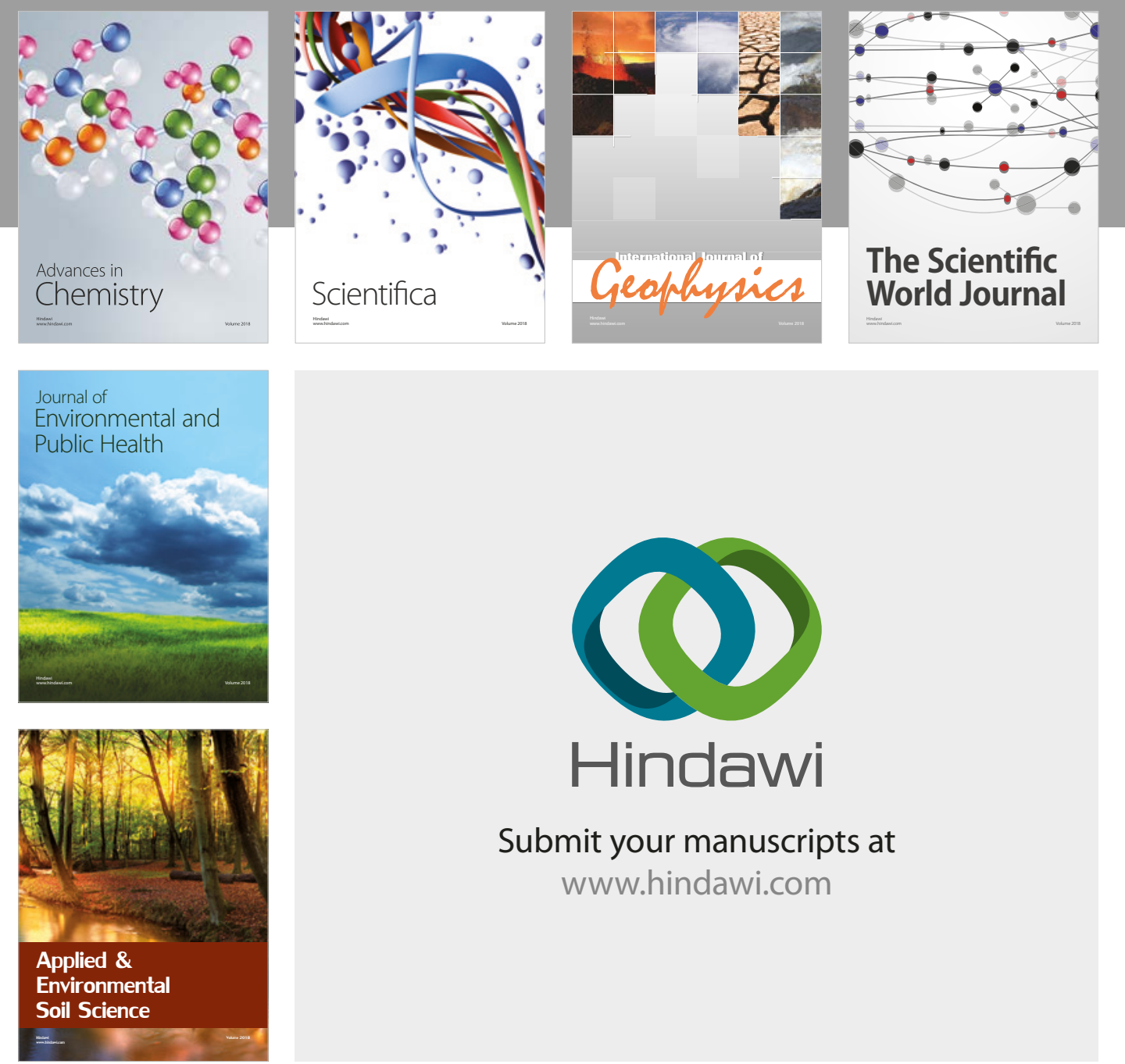

The Scientific

\section{World Journal}
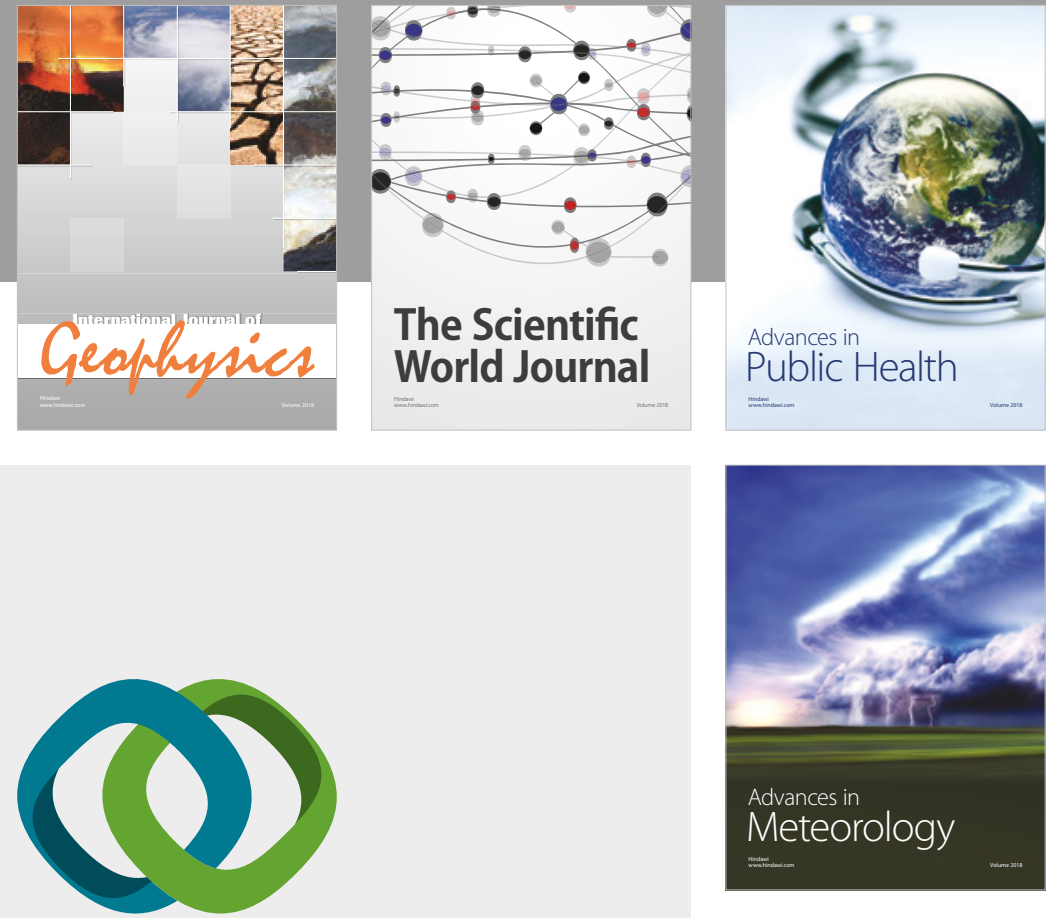

Advan

Public Health

\section{Hindawi}

Submit your manuscripts at

www.hindawi.com
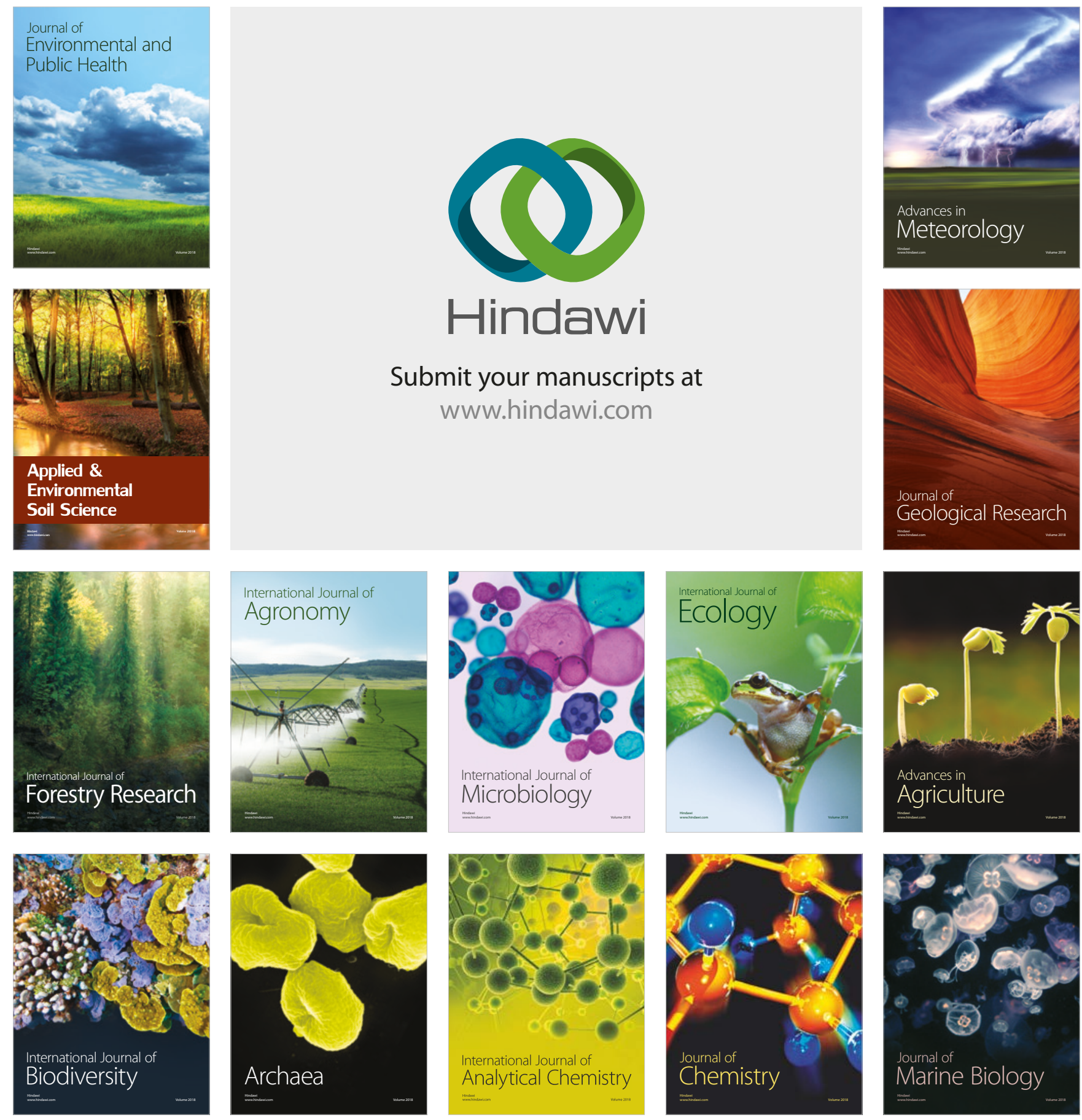